\title{
Evaluation of Consumption of Poultry Products Enriched with Omega-3 Fatty Acids in Anthropometric, Biochemical, and Cardiovascular Parameters
}

\author{
José Arias-Rico, ${ }^{1}$ Martha Izbeth Cerón-Sandoval, ${ }^{2}$ Eli Mireya Sandoval-Gallegos, ${ }^{3}$ \\ Esther Ramírez-Moreno ${ }^{(D)},{ }^{3}$ Trinidad Lorena Fernández-Cortés, ${ }^{3}$ Judith Jaimez-Ordaz, ${ }^{4}$ \\ Elizabeth Contreras-López, ${ }^{4}$ and Javier Añorve-Morga ${ }^{4}{ }^{4}$ \\ ${ }^{1}$ Academic Area of Nurse, Institute of Health Sciences, Pachuca, HGO, Mexico \\ ${ }^{2}$ Public Health, Academic Area of Medicine, Institute of Health Sciences, Pachuca, HGO, Mexico \\ ${ }^{3}$ Interdisciplinary Research Center, Academic Area of Nutrition, Institute of Health Sciences, Circuito Actopan Tilcuautla s/n, \\ Ex-Hacienda La Concepción, 42160 Pachuca, HGO, Mexico \\ ${ }^{4}$ Academic Area of Food Chemistry, Institute of Basic Sciences and Engineering, Autonomous University of Hidalgo State, \\ Carretera Pachuca-Tulancingo Km 4.5, Ciudad del Conocimiento, Colonia Carboneras, 42184 Mineral de la Reforma, HGO, Mexico
}

Correspondence should be addressed to Javier Añorve-Morga; jmorga@uaeh.edu.mx

Received 23 November 2017; Accepted 21 February 2018; Published 29 March 2018

Academic Editor: Stefania Albrizio

Copyright (C) 2018 José Arias-Rico et al. This is an open access article distributed under the Creative Commons Attribution License, which permits unrestricted use, distribution, and reproduction in any medium, provided the original work is properly cited.

An alternative for prevention and treatment for cardiovascular diseases (CVD) is increasing the intake of bioactive compounds as omega-3. However, several countries as México do not consume regularly foods with high content of omega-3, mainly fish products due to cultural, social, and economic factors. Therefore, the addition of omega-3 in other food sources could contribute to completing the requirements established of these fatty acids. To evaluate the effect of the consumption of poultry products supplemented with omega-3 in healthy population, a phase 1, double blind randomized, controlled parallel-group trial was carried out. After 14 weeks, the supplemented group had an increase in HDL, reducing the atherogenic index. The supplementation with omega-3 in poultry products could contribute to a cardioprotective effect. It is necessary to complete studies with a higher evaluation period to determine the improvement in anthropometric and cardiovascular parameters.

\section{Introduction}

The cardiovascular diseases (CVD) are a leading cause of morbidity and mortality worldwide. An estimate of 17.7 million people died from cardiovascular diseases in 2015. World Health Organization (WHO) showed that CVD are the leading cause of mortality in Mexico. Risk factors include tobacco and alcohol use, physical inactivity, unhealthy diets, elevated blood pressure, overweight/obesity, hyperglycemia, and hyperlipidemia [1-5]. Therefore, it is necessary to modify the lifestyles mainly by improving the diet. Several studies show that the consumption of rich food in nutrients improves health. The omega- 3 fatty acids offer a more suitable preventive or therapeutic option for many chronic diseases due to their biological activity $[6,7]$. Various institutions had established recommendations for the consumption of omega-3 as a protective factor against several diseases: the American Dietetic Association (ADA); International Society for the Study of Fatty Acids and Lipids (ISSFAL); French Agency for Food Environment and Occupational Health Safety Omega-3 Report; European Society of Cardiology; Report FAO: FAT and Fatty acid in Human Nutrition; USDA Dietary Guidelines for Americans. These recommendations of omega-3 intake differ from $250 \mathrm{mg}$ up to $4 \mathrm{~g} /$ day, depending on whether it is for prevention $[8,9]$ or treatment of several pathologies [9-14]. In order to achieve this level of daily intake of omega-3, it is recommended to consume 600-660 g of fish minimally per week [9-11], in particular fatty fish such 
as mackerel, lake trout, herring, sardines, albacore tuna, and salmon, or to consume the equivalent in fish oil commercially available as concentrated pharmaceutical preparations [15].

However, Mexico is not a country with a high consumption of fish products due to social, cultural, and economic situations [16]. Compared to the per capita consumption of fish products of countries like Spain, Norway, Japan, Myanmar, Korean Republic, Malaysia, Iceland, and Maldives at $43-165 \mathrm{~kg} /$ year, Mexico's intake of these products is quite low at $4 \mathrm{~kg} /$ year [17]. Therefore, according to other studies, the alternative for increasing intake of omega-3 could include supplemented daily products such as dairy (yogurt, milk, and margarine), juices, chicken, and eggs $[18,19]$. The objective of this research was to evaluate the effects of the consumption of eggs and chicken supplemented with omega-3 on anthropometric, biochemical, and cardiovascular parameters in healthy population.

\section{Material and Methods}

2.1. Subjects and Study Design. The study was a phase 1, double blind randomized, controlled parallel-group trial where 29 volunteers of both sexes participated (17 women and 12 men with an average age of $32 \pm 5.6$ years old, an approximate weight of $74 \pm 18 \mathrm{~kg}$, and height of $1.64 \pm$ $0.084 \mathrm{~m}$ ). They complied with inclusion and exclusion criteria of study. Some participants were excluded from the study due to preexisting conditions, like hypertriglyceridemia and hypercholesterolemia, or because they did not complete the evaluations. At the baseline, participants were randomly assigned to the group that consumed supplemented poultry food (experimental group) or to the control group. Fourteen participants (9 women, 5 men) consumed chicken and eggs supplemented with omega-3 fatty acids and fifteen participants ( 8 women and 7 men) consumed chicken and eggs nonsupplemented with omega-3 fatty acids. Both groups participated for a period of 14 weeks. During this time, participants consumed the poultry products in different preparations; we recommended that they consume the poultry products with fat-free preparations (boiled, grilled, etc.).

The experimental group consumed 250 grams of chicken meat $(\approx 228 \mathrm{mg}$ of omega-3) and 3 eggs $(\approx 1590 \mathrm{mg}$ of omega3 ) each week. The control group consumed the same amount of chicken meat and eggs but without treatment of supplementation. The amount of eggs consumption was calculated according to recommendations established in NOM-043SSA2-2012 [20] and by the Organization INPROVO [21]. Anthropometric measurements, blood samples for biochemical determination, and cardiovascular function data were collected at the baseline and at the 14th week. Subjects followed their regular habits, as physical exercise and regular diet. They signed the informed consent to participate in the intervention. The study protocol was approved by the Ethic Committee of the Health Sciences Institute of the Autonomous University of the State of Hidalgo, Mexico.

2.2. The Chicken Product. A total of 200 poultry males and females (Cobb and Ross strain) were acquired for production of meat and 60 laying hens (Plymouth rock and Rhode
Island strain) for production of eggs. Poultry were housed in stainless steel cages during the period of September to November 2016 and their care was conducted according to the University approved methods. The animals were fed (supplemented and nonsupplemented) with a commercial diet and water provided for ad libitum consumption for 21 days. The commercial diet for supplemented animals was added with $0.5-0.8 \mathrm{~g} /$ day of omega-3 obtained of cod leaver oil. It is the recommended amount to avoid the fish odor and/or flavor in meat and eggs. After 21 days of growth of the animals, the collection of eggs and the obtaining of the meat began. The quality of the meat and eggs supplemented and nonsupplemented with omega-3 was evaluated according to the established standard in NMX-FF-080-SCFI-2006 [22] and PROY-NOM-159-SSA1-2015 [23].

2.3. Anthropometric Measurements. The anthropometric measurements (weight, height, and waist circumference) were evaluated according to the recommendations established by the Secretary of Health (SSA) in Mexico [2426]. The body mass index (BMI) was calculated according to the specifications of the World Health Organization (WHO) [27] and the body composition was measured by body densitometry using air-displacement via the Bod Pod ${ }^{\circledR}$. All testing was done in accordance with the manufacturer's instructions [28] to obtain the values of fat mass (percentage and kilograms), fat-free mass (percentage and kilograms), and weight $(\mathrm{kg})$.

2.4. Biochemical Parameters. Fasting blood samples were collected by venipuncture into vacutainer tubes serum [29], centrifuged at $6500 \mathrm{rpm}$ for 15 minutes (centrifuge brand Hamilton Bell), and stored at $-21^{\circ} \mathrm{C}$ for further analyses. Total cholesterol (TC, optimal value $<200 \mathrm{mg} / \mathrm{dL}$ ), high density lipoprotein (HDL, optimal value $>40 \mathrm{mg} / \mathrm{dL}$ ), triglycerides (TG, optimal value $<150 \mathrm{mg} / \mathrm{dL}$ ), and glucose (optimal value $100-125 \mathrm{mg} / \mathrm{dL}$ ) were determined using commercially available kits (Spinreact ${ }^{\circledR}$ ), considering the specifications of the clinical practices guide for diabetes and dyslipidemias $[30,31]$.

LDL (low density lipoprotein) cholesterol was determined according to the following formula [32]:

$$
\mathrm{LDL} \mathrm{mg} / \mathrm{dL}=\mathrm{TC}-[\mathrm{HDLc}+(\mathrm{Tg}) 5] .
$$

TC is total cholesterol, HDLc is high density lipoprotein cholesterol, and $\mathrm{Tg}$ is triglyceride.

The atherogenic index (AI) was calculated with the following formula:

$$
\text { Castelli Index }=\frac{\text { Total cholesterol }}{\text { HDL cholesterol }}
$$

According with Castelli [33], a low atherogenic index was considered $<4.5,4.5$ to 7 as moderate and $>7$ high.

2.5. Cardiovascular Function. Cardiovascular function was evaluated with the following parameters.

The heart rate was evaluated at rest using a pulsometer $\left(\right.$ MedStar $\left.{ }^{\circledR}\right)$. The ranges were considered optimum with 
TABLE 1: Anthropometric parameters of experimental and control group.

\begin{tabular}{|c|c|c|}
\hline & Week 0 & Week 14 \\
\hline \multicolumn{3}{|l|}{ Experimental group $(n=14)$} \\
\hline Body weight $(\mathrm{Kg})$ & $74.60 \pm 19.20^{\mathrm{a}}$ & $74.5 \pm 19.7^{\mathrm{a}}$ \\
\hline Height (m) & $1.62 \pm 0.09^{\mathrm{a}}$ & $1.62 \pm 0.09^{\mathrm{a}}$ \\
\hline Body mass index (BMI) & $28.1 \pm 6.1^{\mathrm{a}}$ & $28.0 \pm 6.2^{\mathrm{a}}$ \\
\hline Waist circumference $(\mathrm{cm})$ & $90.7 \pm 16.2^{\mathrm{b}}$ & $89.7 \pm 16.2^{\mathrm{a}}$ \\
\hline Body fat (\%) & $33.1 \pm 9.6^{\mathrm{b}}$ & $31.7 \pm 9.8^{\mathrm{a}}$ \\
\hline Body fat (Kg) & $25.5 \pm 11.9^{\mathrm{b}}$ & $24.5 \pm 12.3^{\mathrm{a}}$ \\
\hline Fat-free mass (\%) & $66.9 \pm 9.6^{\mathrm{a}}$ & $68.2 \pm 9.8^{\mathrm{b}}$ \\
\hline Fat-free mass $(\mathrm{Kg})$ & $49.0 \pm 10.5^{\mathrm{a}}$ & $49.9 \pm 10.6^{\mathrm{b}}$ \\
\hline \multicolumn{3}{|l|}{ Control group $(n=15)$} \\
\hline Body weight (Kg) & $83.8 \pm 17.5^{\mathrm{a}}$ & $83.2 \pm 17.9^{\mathrm{a}}$ \\
\hline Height (m) & $1.65 \pm .07^{\mathrm{a}}$ & $1.65 \pm 0.07^{\mathrm{a}}$ \\
\hline Body mass index (BMI) & $30.4 \pm 4.7^{\mathrm{a}}$ & $30.2 \pm 5.1^{\mathrm{a}}$ \\
\hline Waist circumference $(\mathrm{cm})$ & $96.6 \pm 14.4^{\mathrm{a}}$ & $95.2 \pm 14.2^{\mathrm{a}}$ \\
\hline Body fat (\%) & $37.2 \pm 7.9^{b}$ & $35.5 \pm 9.2^{\mathrm{a}}$ \\
\hline Body fat (Kg) & $31.8 \pm 11.0^{\mathrm{a}}$ & $30.1 \pm 12.0^{\mathrm{a}}$ \\
\hline Fat-free mass (\%) & $62.4 \pm 7.6^{\mathrm{a}}$ & $64.4 \pm 9.2^{\mathrm{a}}$ \\
\hline Fat-free mass (Kg) & $52.0 \pm 10.6^{\mathrm{a}}$ & $53.0 \pm 10.4^{\mathrm{b}}$ \\
\hline
\end{tabular}

${ }^{\mathrm{a}, \mathrm{b}}$ Different letters between column values ( 0 and 14th week) indicate significant difference ( $p \leq 0.05$ Student's $t$-test).

values between 65 and 85 beats/minute and considered high with a rate above 85 beats per minute [34].

The arterial pressure was evaluated according to Clinical Practices Guide with an aneroid baumanometer (MedStar $\left.{ }^{\circledR}\right)$ [34]. According to the American Health Association (2017) $120 / 80 \mathrm{mmHg}$ is considered as optimum values [35].

2.6. Bruce Exercise Stress Testing. Bruce Exercise Stress test was evaluated according to the Bruce protocol, recording the electrical activity of the heart that occurs in each heart beat during physical exercise. The subjects performed the maximal exercise tests on an endless band (Wellch Allyn ${ }^{\circledR}$ ), programed for increasing the angle of inclination and speed. The participants walked in an initial slope of $10 \%$ and a speed of $1.7 \mathrm{~km} / \mathrm{h}$; every $3 \mathrm{~min}$ the slope was increased $2 \%$ and speed to $2.5,3.4,4.2,5.0$, and $5.5 \mathrm{~km} / \mathrm{h}$ [36-38]. In addition, every three minutes $(0,3,6,9,12$, and 15 minutes) the heart rate, blood pressure, and electrocardiographic segments were registered [PQ (120-200 milliseconds), QRS-interval (60-100 milliseconds), QT (360 milliseconds), and QTc (340-450 milliseconds)], until the individuals reached $80 \%$ heart rate, considered as the maximum of cardiac capacity. At the end of the test, the duration and recovery time in minutes were recorded. The test was ended when the subject showed exhaustion, fatigue, or inability to maintain a running cadence [39].

2.7. Statistical Analysis. Statistical analysis was performed using the SPSS statistical software (version 23). The ShapiroWilk test was applied to determine the distribution of the data of the variables in the normal curve to identify if the hypothesis would be verified with parametric or nonparametric test. To compare the existence of differences between week 0 and 14th of the intervention in the experimental and control group, a Student's $t$-test was used. Statistical significance was considered as $p$ value $\leq 0.05$ with $95 \%$ confidence intervals. In addition, unpaired $t$-test studies were done together with the analysis of variance between groups for independent samples. The effect size $(\Delta)$ was estimated between the means of the before-after observed differences in the treatment groups using Student's $t$-test.

\section{Results and Discussion}

No subjects reported any side effects derived from the intake of the poultry products consumed in the study. Participants indicted that supplemented poultry products presented intense flavor and texture softer in comparison with the control products and even with major sensorial characteristics in comparison with common commercial products.

The poultry products complied with high quality parameters according to Mexican specifications. The chicken meat was considered to be at the "Extra" category established for products of high quality (NMX-FF-080-SCFI-2006) [22] and the eggs were classified in the "Extra Mexico" category, which describes fresh and high quality products (PROY-NOM-159SSA1-2015) [23].

3.1. Anthropometric Parameters. Table 1 shows the results of anthropometric measurements at the baseline and after the intervention period. In general, both study groups had a BMI higher than 25 . The experimental group had an average BMI of $\approx 28.1$ and values considered as overweight or preobesity and the control group had values of $\approx 30.4 \pm 4.7$ that indicate obesity, according to the WHO classification [40]. In addition, the participants of both groups had high values of fat percentage (33-37\%) and a waist circumference higher than $80 \mathrm{~cm}$ (around 90.7 to $96.6 \mathrm{~cm}$ ). These data coincide with 
TABLE 2: Biochemical parameters of experimental and control group.

\begin{tabular}{|c|c|c|}
\hline & Week 0 & Week 14 \\
\hline \multicolumn{3}{|c|}{ Experimental group $(n=14)$} \\
\hline Glucose (mg/dL) & $91.1 \pm 12.7^{\mathrm{a}}$ & $98.5 \pm 17.2^{\mathrm{a}}$ \\
\hline Cholesterol (mg/dL) & $142.2 \pm 47.4^{\mathrm{a}}$ & $146.1 \pm 39.3^{\mathrm{a}}$ \\
\hline Triglycerides (mg/dL) & $102.0 \pm 19.1^{\mathrm{a}}$ & $116.0 \pm 18.2^{\mathrm{a}}$ \\
\hline HDL (mg/dL) & $51.9 \pm 12.5^{\mathrm{a} *}$ & $60.1 \pm 18.9^{\mathrm{b} *}$ \\
\hline $\mathrm{LDL}(\mathrm{mg} / \mathrm{dL})$ & $69.9 \pm 45.5^{\mathrm{b}}$ & $62.7 \pm 41.9^{\mathrm{a}}$ \\
\hline Atherogenic index & $2.9 \pm 1.1^{\mathrm{b}}$ & $2.6 \pm 1.1^{\mathrm{a} *}$ \\
\hline \multicolumn{3}{|l|}{ Control group $(n=15)$} \\
\hline Glucose (mg/dL) & $97.9 \pm 14.4^{\mathrm{a}}$ & $97.9 \pm 12.2^{\mathrm{a}}$ \\
\hline Cholesterol (mg/dL) & $137.3 \pm 35.8^{\mathrm{a}}$ & $138.1 \pm 45.9^{\mathrm{a}}$ \\
\hline Triglycerides (mg/dL) & $112.9 \pm 26.3^{\mathrm{a}}$ & $119.5 \pm 25.2^{\mathrm{a}}$ \\
\hline HDL (mg/dL) & $72.2 \pm 21.7^{\mathrm{b} *}$ & $54.2 \pm 19.9^{\mathrm{a} *}$ \\
\hline $\mathrm{LDL}(\mathrm{mg} / \mathrm{dL})$ & $42.5 \pm 33.3^{\mathrm{a}}$ & $59.2 \pm 52.2^{\mathrm{b}}$ \\
\hline Atherogenic index & $2.0 \pm 0.66^{\mathrm{a}}$ & $3.3 \pm 3.4^{\mathrm{b} *}$ \\
\hline
\end{tabular}

current trends (ENSANUT 2006 and 2012) that at least 70\% of the Mexican population is overweight and obesity [41].

After the 14th week intervention, both groups improved their anthropometric measurements with a decrease in body fat and an increase in fat-free mass, which could be due to the healthier production conditions of the poultry products (both supplemented and nonsupplemented) in comparison to the conditions of commercial products. The group who consumed supplemented foods with omega-3 had a decrease in waist circumference after the intervention period, but there was no statistical significance between groups. It is possible that longer periods of study would be necessary to establish a significant difference between the two study groups. Other studies showing the improvement of anthropometric variables with the consumption of omega-3 supplement foods or omega-3 supplements (doses of $\approx 2 \mathrm{~g} /$ day) had intervention periods of 4-5 months $[42,43]$. These studies had established that the supplementation with omega-3 could inhibit the differentiation of preadipocytes and an increase of the apoptosis of these cells and/or the regulation of sympathetic nervous system and production of leptin and adiponectin causing the regulation of body fat which leads to changes in the distribution of the ratio of fat-free mass $[43,44]$.

3.2. Biochemical Parameters. At the beginning of the study, the participants had optimum biochemical parameters (glucose, triglycerides, cholesterol, HDL, and LDL) in accordance with the Procedures Manual of the Secretary of Health (SSA) in Mexico [29, 30] and these were maintained in normal conditions until the end of the intervention (Table 2). The statistical analysis showed differences with HDL (high density lipoprotein) levels between the groups at the beginning of the study, which could be affected by several individual factors of the study population (age, diet, stress, tobacco, alcohol, physical activity, etc.) $[33,45,46]$, which must be considered in future supplementation studies. At the end of study, the concentrations of HDL showed a tendency to increase in experimental group (51.9 to $60.1 \mathrm{mg} / \mathrm{dL}$ ) and LDL (low density lipoprotein) decreased (69.9 to $62.7 \mathrm{mg} / \mathrm{dL}$ ) causing the reduction of atherogenic index (2.6 to 2), while the control group showed a contrary behavior. The value of the means difference of HDL was $25.47 \mathrm{mg} / \mathrm{dL}$ (CI 95\% 4.076-46.882, p: 0.021$)$. This represented an increase of $42.5 \%$ of the HDL at baseline concentration. These values reinforce the result that there was a positive impact of the supplementation. The effect of the omega-3 had been found in other studies with supplement foods (yogurt, butter, and pate with fish oil) [4749] accompanied by a significant reduction of LDL and an increase of HDL in blood.

Some authors have established that LDL reduction and HDL increase correlated with intake of omega-3 could be due to a variety of mechanisms. The consumption of marine omega-3 fatty acids could have a relatively neutral effect on LDL and HDL through targeted effects on specific transcription factors and nuclear receptors. Such is the case of PPAR (peroxisome proliferator-activated receptor) that increase HDL by enhancing reverse cholesterol transport [50]. According to some research, the fraction PON1 (paraoxonase), Clusterine, ApoAI, and ApoCIII present in HDL allow regulation in oxidation mechanisms of lipids metabolism [51, 52] and anti-inflammatory process [53] and decrease in proatherogenic lipoproteins (LDL, VLDL) [51, 54]. These functions play an important role in the prevention of atherosclerosis development and other cardiovascular diseases $[12,51,52,55]$. In addition, other studies show that omega-3 significantly reduce LDL due to the enzymatic inhibition of acyl-CoA: 1,2-diaglycerolacyltransferase impacting hepatic synthesis of triglycerides and LDL $[49,56]$, protecting the dysfunction of endothelial cells inhibiting lipogenesis and favoring lipolysis, increasing mitochondrial dynamics, and therefore causing a decrease of chronic diseases.

3.3. Cardiovascular Function Parameters. At the beginning of the study, the experimental and the control group reached 
TABLE 3: Cardiovascular function parameters of experimental and control group.

\begin{tabular}{|c|c|c|}
\hline & week 0 & week 14 \\
\hline \multicolumn{3}{|l|}{ Experimental group $(n=14)$} \\
\hline Test duration (min) & $9.8 \pm 2.1^{\mathrm{a}}$ & $10.3 \pm 1.9^{\mathrm{a}}$ \\
\hline Recovery time (min) & $4.5 \pm 1.7^{\mathrm{a}}$ & $4.0 \pm 1.3^{\mathrm{a}}$ \\
\hline \multicolumn{3}{|l|}{ Electrocardiogram } \\
\hline $\mathrm{PQ}(\mathrm{ms})$ & $157.3 \pm 17.2^{\mathrm{a}}$ & $158.7 \pm 15.8^{\mathrm{a}}$ \\
\hline QRS (ms) & $91.5 \pm 11.8^{\mathrm{a}}$ & $89.0 \pm 9.0^{\mathrm{a}}$ \\
\hline QT (ms) & $413.0 \pm 31.4^{\mathrm{a}}$ & $404.1 \pm 31.1^{\mathrm{a}}$ \\
\hline QTc (ms) & $408.7 \pm 31.0^{\mathrm{a}}$ & $416.5 \pm 20.3^{\mathrm{a}}$ \\
\hline \multicolumn{3}{|l|}{ Heart rate (beats/minute) } \\
\hline Before test & $82.4 \pm 11.1^{\mathrm{b}}$ & $74.3 \pm 10.1^{\mathrm{a}}$ \\
\hline At the test end & $135.7 \pm 15.9^{\mathrm{a}}$ & $152.2 \pm 15.0^{\mathrm{b}}$ \\
\hline \multicolumn{3}{|l|}{ Blood pressure $\mathrm{mm} / \mathrm{Hg}$} \\
\hline Systolic before test & $110.5 \pm 11.1^{\mathrm{a}}$ & $106.1 \pm 9.2^{\mathrm{a}}$ \\
\hline Systolic at the test end & $132.2 \pm 11.1^{\mathrm{a}}$ & $134.6 \pm 12.4^{\mathrm{a}}$ \\
\hline Diastolic before test & $78.5 \pm 7.4^{\mathrm{b}}$ & $72.8 \pm 6.1^{\mathrm{a}}$ \\
\hline Diastolic at the test end & $84.2 \pm 12.8^{\mathrm{b}}$ & $74.2 \pm 7.3^{\mathrm{a}}$ \\
\hline \multicolumn{3}{|l|}{ Control Group $(n=15)$} \\
\hline Test duration (min) & $10.6 \pm 3.7^{\mathrm{a}}$ & $10.6 \pm 3.5^{\mathrm{a}}$ \\
\hline Recovery time (min) & $4.8 \pm 1.7^{\mathrm{a}}$ & $4.5 \pm 1.6^{\mathrm{a}}$ \\
\hline \multicolumn{3}{|l|}{ Electrocardiogram } \\
\hline PQ (ms) & $158.0 \pm 17.4^{\mathrm{a}}$ & $156.4 \pm 16.4^{\mathrm{a}}$ \\
\hline QRS (ms) & $98.2 \pm 12.4^{\mathrm{a}}$ & $96.5 \pm 12.5^{\mathrm{a}}$ \\
\hline QT (ms) & $407.6 \pm 36.1^{\mathrm{a}}$ & $403.2 \pm 4.0^{\mathrm{a}}$ \\
\hline QTc (ms) & $417.3 \pm 22.2^{\mathrm{a}}$ & $416.8 \pm 23.4^{\mathrm{a}}$ \\
\hline \multicolumn{3}{|l|}{ Heart rate } \\
\hline Before test & $74.3 \pm 11.1^{\mathrm{a}}$ & $78.2 \pm 13.9^{\mathrm{b}}$ \\
\hline At the test end & $139.0 \pm 19.1^{\mathrm{a}}$ & $144.1 \pm 22.1^{\mathrm{a}}$ \\
\hline \multicolumn{3}{|l|}{ Blood pressure $\mathrm{mm} / \mathrm{Hg}$} \\
\hline Systolic before test & $109.6 \pm 9.3^{\mathrm{a}}$ & $107.0 \pm 12.2^{\mathrm{a}}$ \\
\hline Systolic at the test end & $131.0 \pm 12.5^{\mathrm{a}}$ & $134.0 \pm 25.6^{\mathrm{a}}$ \\
\hline Diastolic before test & $76.0 \pm 8.7^{\mathrm{a}}$ & $74.6 \pm 7.4^{\mathrm{a}}$ \\
\hline Diastolic at the test end & $81.3 \pm 7.4^{\mathrm{a}}$ & $77.6 \pm 10.4^{\mathrm{a}}$ \\
\hline
\end{tabular}

${ }^{\mathrm{a}, \mathrm{b}}$ Different letters between column values ( 0 and 14th week) indicate significant difference ( $p \leq 0.05$ Student's $t$-test).

$80 \%$ of their cardiac capacity at 10 minutes of physical effort without significant changes after the 14th week of study. In addition, the time range of the electrocardiographic segments (PQ, QRS, QT, and QTc) in both groups was normal at each evaluation time, discarding the presence of cardiac arrhythmias or other abnormalities that could affect the performance of the stress test during the evaluation period. The basal heart rate and arterial pressure of the study groups had normal ranges; however, after the 14th week only the experimental group showed a decrease in both parameters changing from normal ranges to optimum (heart rate, diastolic pressure before and after the test) (Table 3 ). The participants of the experimental group had less fatigue and less heart strain at the 14th week having a normalizing effect on the diastolic pressure according with other studies [5759]. However, these changes were not statistically significant between the experimental group and the control group. Previously, we have mentioned that these differences could become significant if the time study had been extended.

Several studies [57-59] had shown less cardiac effort after supplementation with omega-3, which could be due to several mechanisms, mainly due to the function of these polyunsaturated fats on the permeability and fluidity of the cell membrane improving nervous impulse and muscular contraction. Other authors [60] have established that the aldosterone secretion, increased nitric oxide, and a higher production of prostaglandins are related to a reduction of platelet aggregation contributing with anti-inflammatory 
process which allows the regulation of blood pressure and thus the improvement of cardiovascular function.

\section{Conclusion}

The consumption of supplemented poultry products with omega-3 increased the HDL concentration and decreased atherogenic index related with cardiovascular diseases improving the overall health status in the test population. Therefore, poultry products supplemented with omega-3 could be a viable alternative in populations where the consumption of fish products is low. Hence, it is important to replicate these studies with the extension of the time study and the inclusion of other foods.

\section{Conflicts of Interest}

The authors declare that there are no conflicts of interest regarding the publication of this paper.

\section{Acknowledgments}

The authors acknowledge the support of the Universidad Autónoma del Estado de Hidalgo (PFCE-2017-18) and the concession of a master fellowship Consejo Nacional de Ciencia y Tecnología: CONACyT 422956 cvu 709822 for Martha Izbeth Cerón Sandoval. The authors are grateful to colleagues Villanueva-Sanchez Javier and Jiménez-Sánchez Reyna Cristina for their technical assistance.

\section{References}

[1] S. S. Lim, T. Vos, A. D. Flaxman, G. Danaei, K. Shibuya, and H. Adair-Rohani, "A comparative risk assessment of burden of disease and injury attributable to 67 risk factors and risk factor clusters in 21 regions, 1990-2010: a systematic analysis for the Global Burden of Disease Study," The Lancet, vol. 15, pp. 98592224, 2010.

[2] World Health Organization, WHO. Noncommunicable diseases. Junio 2017; cite, enero 2018. http://www.who.int/mediacentre/factsheets/fs355/en/.

[3] P. W. F. Wilson, R. B. D’Agostino, D. Levy, A. M. Belanger, H. Silbershatz, and W. B. Kannel, "Prediction of coronary heart disease using risk factor categories," Circulation, vol. 97, no. 18, pp. 1837-1847, 1998.

[4] W. B. Kannel, R. B. D’Agostino, L. Sullivan, and P. W. F. Wilson, "Concept and usefulness of cardiovascular risk profiles," American Heart Journal, vol. 148, no. 1, pp. 16-26, 2004.

[5] J. Pérez-Jiménez, J. Serrano, M. Tabernero et al., "Effects of grape antioxidant dietary fiber in cardiovascular disease risk factors," Nutrition Journal, vol. 24, no. 7-8, pp. 646-653, 2008.

[6] S. Lorente-Cebrián, A. G. V. Costa, S. Navas-Carretero, M. Zabala, J. A. Martínez, and M. J. Moreno-Aliaga, "Role of omega-3 fatty acids in obesity, metabolic syndrome, and cardiovascular diseases: a review of the evidence," Journal of Physiology and Biochemistry, vol. 69, no. 3, pp. 633-651, 2013.

[7] P. Nestel, P. Clifton, D. Colquhoun et al., "Indications for Omega-3 Long Chain Polyunsaturated Fatty Acid in the Prevention and Treatment of Cardiovascular Disease," Heart, Lung and Circulation, vol. 24, no. 8, pp. 769-779, 2015.
[8] K. H. Weylandt, S. Serini, Y. Q. Chen et al., "Omega-3 polyunsaturated fatty acids: the way forward in times of mixed evidence," BioMed Research International, vol. 2015, Article ID 143109, 24 pages, 2015.

[9] B. R. Valenzuela, IG. Morales, A. M. Gonzßlez, P. J. Morales, C. J. Sanhueza, and B. A. Valenzuela, "Ácidos grasos poliinsaturados de cadena larga w-3 y enfermedad cardiovascular," Revista chilena de nutrición, vol. 41, pp. 319-327, 2014.

[10] J. L. Breslow, "n-3 Fatty acids and cardiovascular disease," American Journal of Clinical Nutrition, vol. 83, no. 6, pp. 1477S1482S, 2006.

[11] D. S. Siscovick, T. A. Barringer, A. M. Fretts et al., "Omega3 Polyunsaturated Fatty Acid (Fish Oil) Supplementation and the Prevention of Clinical Cardiovascular Disease: A Science Advisory from the American Heart Association," Circulation, vol. 135, no. 15, pp. e867-e884, 2017.

[12] M. E. Surette, "The science behind dietary omega-3 fatty acids," Canadian Medical Association Journal, vol. 178, no. 2, pp. 177$180,2008$.

[13] A. Mohebi-Nejad and B. Bikdeli, "Omega-3 Supplements and Cardiovascular Diseases," Tanaffos, vol. 13, no. 1, p. 14, 2014.

[14] P. M. Kris-Etherton, W. S. Harris, and L. J. Appel, “Omega-3 fatty acids and cardiovascular disease: new recommendations from the American Heart Association," Arteriosclerosis, Thrombosis, and Vascular Biology, vol. 23, no. 2, pp. 151-152, 2003.

[15] P. Saravanan, N. C. Davidson, E. B. Schmidt, and P. C. Calder, "Cardiovascular effects of marine omega-3 fatty acids," The Lancet, vol. 376, no. 9740, pp. 540-550, 2010.

[16] B. E. Durazo, C. B. H. Chávez, P. M. E. González, and G. B. Nava, "Estudio descriptivo sobre el consumo de pescados y mariscos en una muestra de la comunidad universitaria en Ensenada, México," Researchgate, no. 11, pp. 1-19, 2013.

[17] A. Cantoral, C. Batis, and N. Basu, "National estimation of seafood consumption in Mexico: Implications for exposure to methylmercury and polyunsaturated fatty acids," Chemosphere, vol. 174, pp. 289-296, 2017.

[18] M. I. Castro-González, "Acidos grasos omega 3: beneficios y fuentes," Interciencia, vol. 27, pp. 128-136, 2002.

[19] C. C. Gómez, L. L. M. Bermejo, and K. V. Loria, "Importance of a balanced omega 6/omega 3 ratio for the maintenance of health Nutritional recommendations," Nutrición Hospitalaria, vol. 26, pp. 323-329, 2011.

[20] Servicio Basicos de Salud. Promoción y Educación para la Salud en Materia Alimentaria Criterios para Brindar Orientación. Norma Oficial Mexicana NOM-043-SSA2-2012. Diario oficial de la federación, 2012.

[21] Organización Interprofesional del Huevo y sus Productos (INPROVO) "Recomendaciones de consumo". Madrid. 2014. http://huevo.org.es/huevo_salud_alimentacion_saludable_recomendaciones_consumo.asp.

[22] Productos Avicolas-Carne de Pollo en Engorda en la Canal y en Piezas. Norma Mexicana NMX-FF-080-SCFI-2006. Secretar $\varphi$ a de Economia. Direcci $\leq \mathrm{n}$ General de Normas,.

[23] Productos y Sevicios. Huevo y sus Productos. Disposiciones y Especificaciones Sanitarias. Método de prueba. Proyecto de Norma Oficial Mexicana PROY-NOM-159-SSA1-2015, Secretaría de Salud. Diario Oficial de la Federación, 2015.

[24] Manual de Procedimientos. Toma de medidas clínicas y antropométricas en el adulto y adulto mayor. Secretaría de Salud. Subsecretraría de prevención y protección de la salud Cndve, 2002. 
[25] M. O. Velázquez, E. A. Lara, O. F. Tapia et al., Manual de procedimientos, toma de medidas clínicas y antropométricas en el adulto y adulto mayor, http://www.salud.gob.mx/unidades/ cdi/documentos/DOCSAL7518.pdf.

[26] L. C. Milián, C. h. F. Moncada, and L. E. Borjas, Manual de medidas antropométricas" 1 era ed. Costa Rica: Saltra/IRETUNA, 2014. http://repositorio.una.ac.cr/bitstream/handle/11056/ 8632/MANUAL\%20ANTROPOMETRIA.pdf. SBN: 978-9968924-18-4.

[27] World Health Organization, WHO. Obesity and overweight. 2016 [cited 2017 Febrero], http://www.who.int/mediacentre/factsheets/fs311/en/.

[28] F. A. Suverza and N. K. Haua, Manual de antropometría para la evaluación del estado nutricio en el adulto, In: Universidad Iberoamericana AC, editor. México, D.F, 2009. ISBN: 978-607417-028-3.

[29] Medical Laboratories. Blood Specimen Collection and Processing. 2016 https://www.geisingermedicallabs.com/catalog/blood specimens.shtml.

[30] Diagnostico y Tratamiento de Dislipidemias (Hipercolesterolemia) en el Adulto IMSS-233-09. Secretaría de Salud. Catálogo Maestro de Guías de Practica Clínicas. CENETEC, Centro Nacional de Excelencia Tecnologica en Salud, 2016.

[31] Tratamiento de la diabetes mellitus tipo 2 en el primer nivel de atencion. en el adulto. IMSS-718-14. Secretaría de Salud. Catálogo Maestro de Guías de Practica Clínicas. CENETEC, Centro Nacional de Excelencia Tecnologica en Salud, 2014.

[32] W. T. Friedewald, R. I. Levy, and D. S. Fredrickson, "Estimation of the concentration of low-density lipoprotein cholesterol in plasma, without use of the preparative ultracentrifuge," Clinical Chemistry, vol. 18, no. 6, pp. 499-502, 1972.

[33] W. P. Castelli, "Epidemiology of coronary heart disease: The Framingham Study," American Journal of Medicine, vol. 76, no. 2, pp. 4-12, 1984.

[34] Diagnóstico y tratamiento de la hipertensión arterial en el primer nivel de atención. IMSS-076-08-2014. Secretaría de Salud. Catálogo Maestro de Guías de Practica Clínicas. CENETEC, Centro Nacional de Excelencia Tecnologica en Salud, 2014

[35] R. M. Carey and P. K. Whelton, Prevention, detection, evaluation, and management of high blood pressure in adults: synopsis of the 2017, American College of Cardiology/American Heart Association hypertension guideline. Annals of Internal Medicine, 2018.

[36] R. A. Bruce, J. R. Blackmon, J. W. Jones, and G. Strait, "Exercising testing in adult normal subjects and cardiac patients," Pediatrics, vol. 32, pp. 742-756, 1963.

[37] J. Aristizázal, H. Jaramillo, and M. Rico, "Pautas generales para la prescripci $\leq \mathrm{n}$ de la actividad $f \varphi$ sica en pacientes con enfermedades cardiovasculares," Latreia, vol. 16, no. 3, pp. 240253, 2003.

[38] F. Arós, A. Boraita, E. Alegría, Á. Alonso, A. Barbají, R. Lamiel et al., "Guías de práctica clínica de la Sociedad Española de Cardiología en pruebas de esfuerzo," Revista española de Cardiología, vol. 53, no. 08, pp. 1063-1094, 2000.

[39] BR. Chaitman, "Exercise stress testing," in Braunwald's heart disease. A textbook of cardiovascular medicine, DP. Zipes, P. Libby, RO. Bonow, and E. Braunwald, Eds., vol. 1, pp. 153-185, Elsevier Saunders, Philadelphia, PA, USA, 7th edition, 2005.

[40] World Health Organization (WHO). Obesity. 2017. http://www .who.int/features/factfiles/obesity/es/.
[41] J. Gutiérrez, J. Rivera Dommarco, T. Shamah Levy, S. Villapaldo Hernández, A. Franco, L. Cuevas et al., Encuesta nacional de salud y nutrición, Instituto de Salud Pública, Cuernavaca, México, 2012.

[42] P. Celada, G. Delgado-Pando, B. Olmedilla-Alonso, F. JiménezColmenero, M. Ruperto, and F. J. Sánchez-Muniz, "Impact of improved fat-meat products consumption on anthropometric markers and nutrient intakes of male volunteers at increased cardiovascular risk," Nutrición Hospitalaria, vol. 32, no. 2, pp. 710-721, 2015.

[43] O. González-Acevedo, JF. Hernández-Sierra, A. SalazarMartínez, PB. Mandeville et al., "Efecto de la suplementación de omega 3 sobre IMC, ICC y composición corporal en mujeres obesas," Archivos Latinoamericanos de Nutrición ALAN, vol. 63, no. 3, pp. 224-231, 2018.

[44] A. A. Sneddon, F. Tsofliou, C. L. Fyfe et al., "Effect of a conjugated linoleic acid and $\omega-3$ fatty acid mixture on body composition and adiponectin," Obesity, vol. 16, no. 5, pp. 1019-1024, 2008.

[45] J. Okęcka-Szymańska, E. Hübner-Woźniak, I. Piątkowska, and M. Malara, "Effects of age, gender and physical activity on plasma lipid profile," Biomedical Human Kinetics, vol. 3, pp. 1-5, 2011.

[46] P. W. Siri-Tarino, "Effects of diet on high-density lipoprotein cholesterol," Current Atherosclerosis Reports, vol. 13, no. 6, pp. 453-460, 2011.

[47] C. Dawczynski, L. Martin, A. Wagner, and G. Jahreis, "n-3 LCPUFA-enriched dairy products are able to reduce cardiovascular risk factors: a double-blind, cross-over study,' Clinical Nutrition, vol. 29, no. 5, pp. 592-599, 2010.

[48] B. Kirkhus, A. Lamglait, K.-E. Eilertsen et al., "Effects of similar intakes of marine n-3 fatty acids from enriched food products and fish oil on cardiovascular risk markers in healthy human subjects.", British Journal of Nutrition, vol. 107, no. 9, pp. 13391349, 2012.

[49] J. Turgeon, S. Dussault, F. Maingrette et al., "Fish oil-enriched diet protects against ischemia by improving angiogenesis, endothelial progenitor cell function and postnatal neovascularization," Atherosclerosis, vol. 229, no. 2, pp. 295-303, 2013.

[50] M. H. Davidson, "Mechanisms for the hypotrygliceridemic effect of marine omega -3 fatty acids," The American Journal of Cardiology, vol. 98, no. 4A, pp. 27i-33i, 2006.

[51] E. Burillo, R. Mateo-Gallego, A. Cenarro et al., "Beneficial effects of omega-3 fatty acids in the proteome of high-density lipoprotein proteome," Lipids in Health and Disease, vol. 11, article no. 116, 2012.

[52] C. Zheng, C. Khoo, J. Furtado, and F. M. Sacks, "Apolipoprotein C-III and the metabolic basis for hypertriglyceridemia and the dense low-density lipoprotein phenotype," Circulation, vol. 121, no. 15, pp. 1722-1734, 2010.

[53] H. Poudyal, S. K. Panchal, V. Diwan, and L. Brown, "Omega3 fatty acids and metabolic syndrome: effects and emerging mechanisms of action," Progress in Lipid Research, vol. 50, no. 4, pp. 372-387, 2011.

[54] T. Vaisar, S. Pennathur, P. S. Green et al., "Shotgun proteomics implicates protease inhibition and complement activation in the antiinflammatory properties of HDL," The Journal of Clinical Investigation, vol. 117, no. 3, pp. 746-756, 2007.

[55] B. De Roos, A. Geelen, K. Ross et al., "Identification of potential serum biomarkers of inflammation and lipid modulation that are altered by fish oil supplementation in healthy volunteers," Journal of Proteomics, vol. 8, no. 10, pp. 1965-1974, 2008. 
[56] J. G. Gormaz, R. Rodrigo, L. A. Videla, and M. Beems, "Biosynthesis and bioavailability of long-chain polyunsaturated fatty acids in non-alcoholic fatty liver disease," Progress in Lipid Research, vol. 49, no. 4, pp. 407-419, 2010.

[57] L. Peñailillo Escarate, K. Mackay Phillips, N. Serrano Duarte et al., "Efectos de la suplementación de omega-3 y entrenamiento de intervalos de alta intensidad en el rendimiento físico, presión arterial y composición corporal en individuos sedentarios con sobrepeso," Nutrición Hospitalaria, vol. 33, no. 4, 2016.

[58] R. A. Vaughan, R. Garcia-Smith, M. Bisoffi, C. A. Conn, and K. A. Trujillo, "Conjugated linoleic acid or omega 3 fatty acids increase mitochondrial biosynthesis and metabolism in skeletal muscle cells," Lipids in Health and Disease, vol. 11, article no. 142, 2012.

[59] L. Gravina, F. F. Brown, L. Alexander et al., "N-3 fatty acid supplementation during 4 weeks of training leads to improved anaerobic endurance capacity, but not maximal strength, speed, or power in soccer players," International Journal of Sport Nutrition and Exercise Metabolism, vol. 27, no. 4, pp. 305-313, 2017.

[60] J. Cabo, R. Alonso, and P. Mata, "Omega-3 fatty acids and blood pressure," British Journal of Nutrition, vol. 107, supplement 2, pp. S195-S200, 2012. 


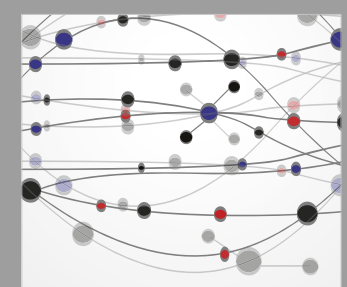

The Scientific World Journal
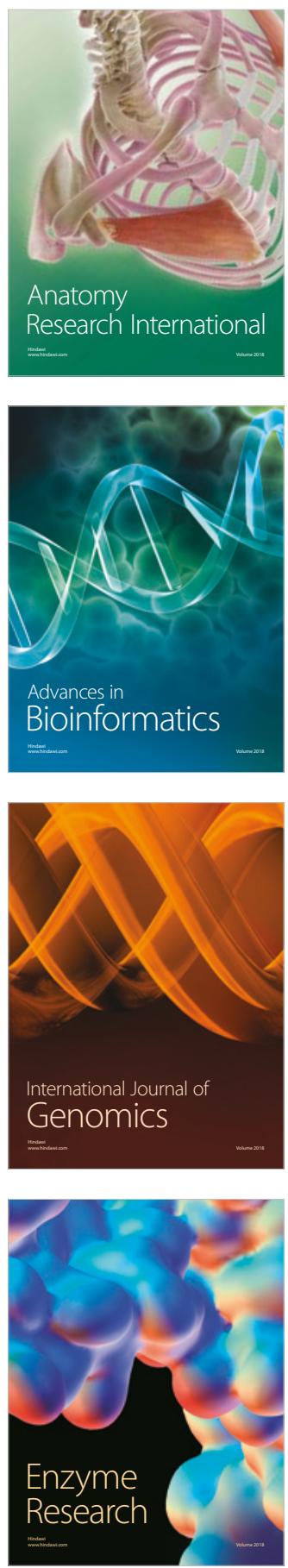
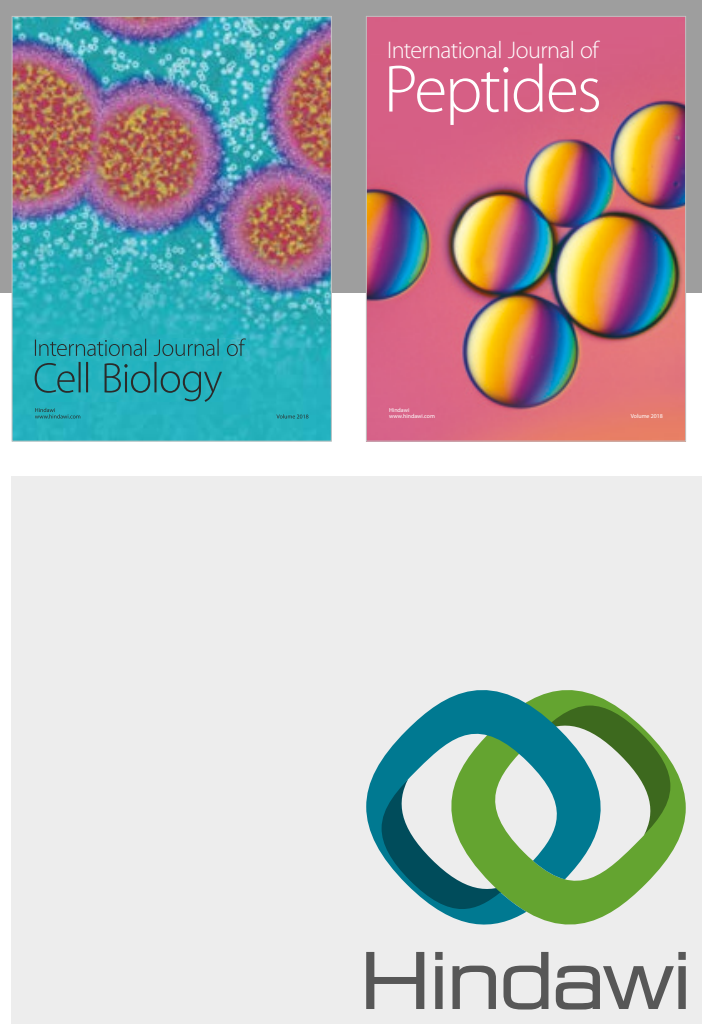

Submit your manuscripts at

www.hindawi.com
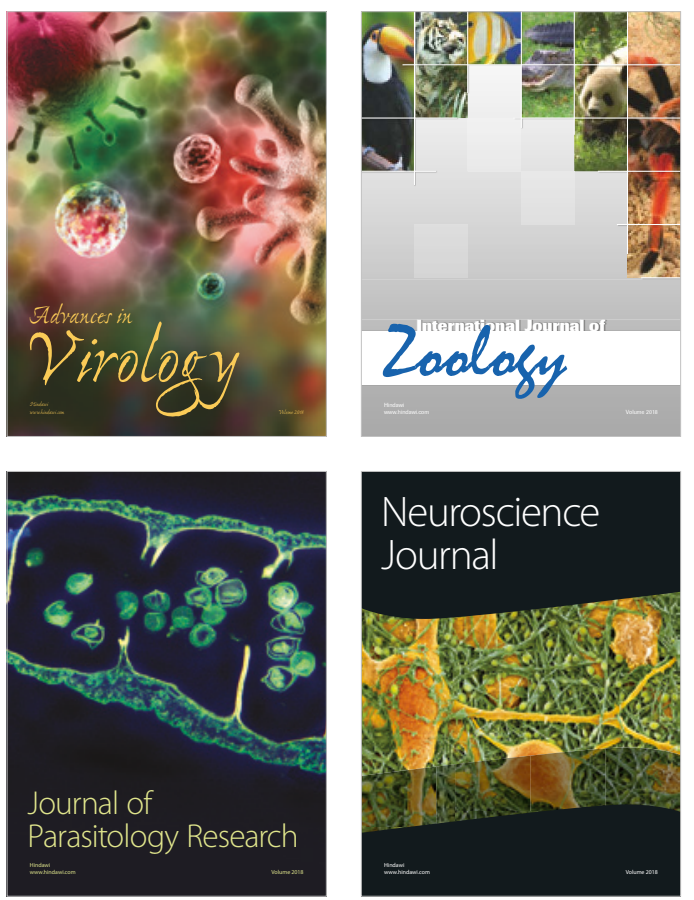
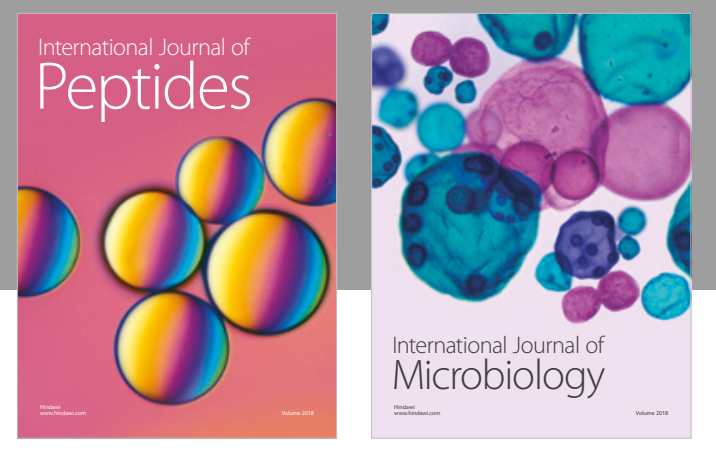

nternational Journal of Microbiology
Journal of
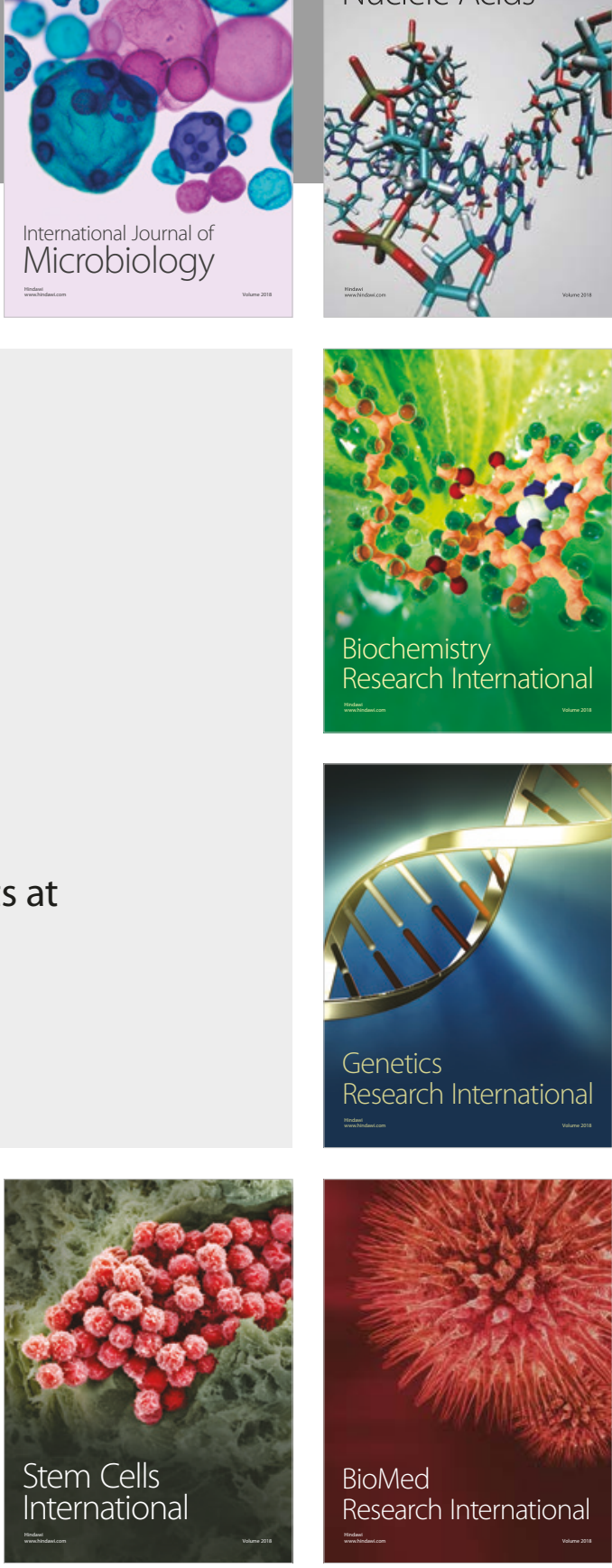
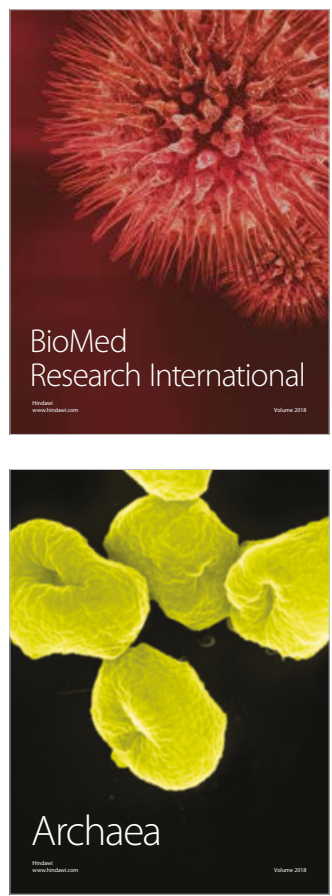